\title{
Integrin-mediated resistance to epidermal growth factor receptor-targeted therapy: an inflammatory situation
}

\author{
Wells S Brown and Michael K Wendt
}

\begin{abstract}
Targeting the function of epidermal growth factor receptor (EGFR) has failed as an effective clinical option for breast cancer. Understanding the drivers of inherent resistance has been a challenge. One possible mechanism is the acquisition of stem-like properties through the process of epithelial-mesenchymal transition. A recent study by Seguin and colleagues adds to our understanding of this process by demonstrating a functional role for unligated av $\beta 3$ integrin in mediating a stem-like phenotype and facilitating resistance to EGFR-targeted therapy via enhanced downstream coupling to a KRAS:RalB:NF-KB pathway. Importantly, the identified mechanism may reveal a possible strategy for sensitizing breast cancer cells to EGFR-targeted therapies.
\end{abstract}

\section{Background}

Expression of epidermal growth factor receptor (EGFR) serves as a robust marker for the basal-like subtype of breast cancer $(\mathrm{BC})$ and a biomarker for decreased survival times of $\mathrm{BC}$ patients [1,2]. Moreover, numerous studies have established functional roles for epidermal growth factor/EGFR in facilitating the systemic dissemination of $\mathrm{BC}$ cells [3-5]. However, clinical trials targeting EGFR for the treatment of $\mathrm{BC}$ have produced disappointing results [6,7]. These contrasting findings suggest that while BC cells utilize EGFR signaling to facilitate certain aspects of tumor progression, they become inherently resistant to inhibition of EGFR function during the later stages of disease progression. Defining the drivers of this type of inherent resistance has been

\footnotetext{
* Correspondence: mwendt@purdue.edu

Department of Medicinal Chemistry and Molecular Pharmacology, Purdue University, West Lafayette, IN 47906, USA
}

difficult because, as opposed to acquired resistance, these cells are resistant prior to therapeutic intervention.

Integrin receptors are vital conduits that mediate cellcell and cell-extracellular matrix interactions, as well as initiating intracellular signaling cascades promoting survival and migration. The complexity of signaling events that emanate from these receptors has prevented effective targeting of their function for the treatment of $\mathrm{BC}$. $\beta 3$ integrin is a well established marker of highly aggressive and metastatic $\mathrm{BC}$ [8]. Furthermore, aberrant expression of $\beta 3$ integrin is strongly related to epithelialmesenchymal transition [9], a process involved in several aspects of tumor metastasis [10], generation of a stemlike state [11] and resistance to EGFR-targeted therapies [12]. However, the functional role of $\beta 3$ integrin in mediating a stem-like state and resistance to EGFR-targeted therapies has remained undefined.

\section{The article}

In a recent article published in Nature Cell Biology, Seguin and colleagues [13] demonstrate the importance of an $\alpha v \beta 3: K R A S: R a l B: N F-\kappa B$ signaling pathway in driving a stem-like state and resistance to EGFR-targeted therapies. In this work, the authors first demonstrate that patientderived tumor tissues can be enriched in tumor-initiating potential based on expression of $\beta 3$ integrin. Correspondingly, depletion of $\beta 3$ integrin in tumor cell lines decreases stem-like cells as measured by several assays. Importantly, use of the nonadherent tumor sphere assay was the first indication that the role of $\beta 3$ integrin in modulating tumor initiating capacity was independent of its role in cell adhesion. Next, the authors demonstrate that $\beta 3$ integrin is necessary and sufficient to impart growth resistance to the EGFR inhibitor erlotinib. Interestingly, expression of $\beta 3$ integrin had no impact on the response to nucleoside analogues or DNA crosslinking drugs, suggesting this result is restricted to targeted therapies. Moving downstream of $\beta 3$ integrin the 
authors expand upon their previous findings [14] and show that the ability of $\beta 3$ integrin to facilitate drug resistance does not function through the more traditional focal adhesion complex, but instead via a KRAS:RalB: TBK1:NF- $\kappa B$ pathway that is facilitated by galectin-3. Finally, the authors demonstrate that combining erlotinib with the proteasome inhibitor bortezomib can overcome $\beta 3$ integrin-mediated resistance to EGFR inhibition (EGFRi).

\section{Viewpoint}

With the enhanced specificity and reduced toxicity of targeted molecular therapies comes the drawback of inherent and acquired resistance. As stated above, several lines of evidence point to EGFRi as an effective therapeutic strategy for $\mathrm{BC}$, but these predications have not been borne out in the clinic. Together with previous findings, the current study suggests that targeting of galectin-3, RalB [15] or TBK1 [16] may actually be capable of inducing sensitivity to EGFRi therapies. Of particular importance is the treatment of triple-negative $\mathrm{BCs}$, which currently lack any effective targeted therapeutic option. With regard to the other $\mathrm{BC}$ subtypes, whether this $\beta 3: \mathrm{NF}-\mathrm{kB}$ mechanism of resistance takes place during acquisition of resistance to HER2-targeted or endocrine-targeted therapies also remains to be determined [17]. Similar to EGFRi, vascular endothelial growth factor (VEGF)-targeted therapy has only had limited success in BC treatment. Several clinical trials currently underway are combining the VEGF-targeted agent bevacizumab with bortezomib, but further investigations into the role of $\beta 3$ integrin:NF- $\mathrm{kB}$ in this resistance process are clearly warranted.

Mechanistically, the finding that $\beta 3$ integrin induces stemness during the unligated state is very intriguing. Indeed, cilengitide is a cyclic peptide antagonist of $\alpha v$ binding that is currently in clinical trials for the treatment of multiple cancers. However, the current study demonstrates that this compound is unable to target the stem-like cells that drive drug resistance, suggesting it may not be an effective therapy for BC. Specificity remains a major drawback to compounds targeting the NF-кB pathway. Despite this, several ongoing clinical trials are exploring the combination of bortezomib with erlotinib and other targeted therapies [18]. Using $\beta 3$ integrin as a histological marker, these clinical approaches can be evaluated for eradication of the stem-like cell population in the hopes of unlocking the potential of erlotinib as an effective BC therapy.

\section{Abbreviations}

BC: Breast cancer; EGFR: Epidermal growth factor receptor; EGFRi: Epidermal growth factor receptor inhibition; VEGFR: Vascular endothelial growth factor receptor.
Competing interests

The authors declare that they have no competing interests.

Published online: 23 September 2014

\section{References}

1. Tischkowitz M, Brunet J-S, Bégin LR, Huntsman DG, Cheang MCU, Akslen LA, Nielsen TO, Foulkes WD: Use of immunohistochemical markers can refine prognosis in triple negative breast cancer. BMC Cancer 2007, 7:134

2. Livasy CA, Karaca G, Nanda R, Tretiakova MS, Olopade OI, Moore DT, Perou CM: Phenotypic evaluation of the basal-like subtype of invasive breast carcinoma. Mod Pathol Off J U S Can Acad Pathol Inc 2006, 19:264-271

3. Wyckoff J, Wang W, Lin EY, Wang Y, Pixley F, Stanley ER, Graf T, Pollard JW, Segall J, Condeelis J: A paracrine loop between tumor cells and macrophages is required for tumor cell migration in mammary tumors. Cancer Res 2004, 64:7022-7029.

4. Wendt MK, Smith JA, Schiemann WP: Transforming growth factor- $\beta$ induced epithelial-mesenchymal transition facilitates epidermal growth factor-dependent breast cancer progression. Oncogene 2010, 29:6485-6498

5. Huang M, Anand S, Murphy EA, Desgrosellier JS, Stupack DG, Shattil SJ, Schlaepfer DD, Cheresh DA: EGFR-dependent pancreatic carcinoma cell metastasis through Rap1 activation. Oncogene 2012, 31:2783-2793.

6. Dickler MN, Cobleigh MA, Miller KD, Klein PM, Winer EP: Efficacy and safety of erlotinib in patients with locally advanced or metastatic breast cancer. Breast Cancer Res Treat 2009, 115:115-121.

7. Dickler MN, Rugo HS, Eberle CA, Brogi E, Caravelli JF, Panageas KS, Boyd J, Yeh B, Lake DE, Dang CT, Gilewski TA, Bromberg JF, Seidman AD, D'Andrea GM, Moasser MM, Melisko M, Park JW, Dancey J, Norton L, Hudis CA: A phase II trial of erlotinib in combination with bevacizumab in patients with metastatic breast cancer. Clin Cancer Res Off J Am Assoc Cancer Res 2008, 14:7878-7883.

8. Sloan EK, Pouliot N, Stanley KL, Chia J, Moseley JM, Hards DK, Anderson RL: Tumor-specific expression of alphavbeta3 integrin promotes spontaneous metastasis of breast cancer to bone. Breast Cancer Res 2006, 8:R20.

9. Galliher AJ, Schiemann WP: Beta3 integrin and Src facilitate transforming growth factor-beta mediated induction of epithelialmesenchymal transition in mammary epithelial cells. Breast Cancer Res 2006, 8:R42.

10. Wendt MK, Tian M, Schiemann WP: Deconstructing the mechanisms and consequences of TGF- $\beta$-induced EMT during cancer progression. Cell Tissue Res 2012, 347:85-101.

11. Mani SA, Guo W, Liao M-J, Eaton EN, Ayyanan A, Zhou AY, Brooks M, Reinhard F, Zhang CC, Shipitsin M, Campbell LL, Polyak K, Brisken C, Yang J, Weinberg RA: The epithelial-mesenchymal transition generates cells with properties of stem cells. Cell 2008, 133:704-715

12. Sharma SV, Lee DY, Li B, Quinlan MP, Takahashi F, Maheswaran S, McDermott U, Azizian N, Zou L, Fischbach MA, Wong K-K, Brandstetter K, Wittner B, Ramaswamy S, Classon M, Settleman J: A chromatin-mediated reversible drug-tolerant state in cancer cell subpopulations. Cell 2010, 141:69-80.

13. Seguin L, Kato S, Franovic A, Camargo MF, Lesperance J, Elliott KC, Yebra M, Mielgo A, Lowy AM, Husain H, Cascone T, Diao L, Wang J, Wistuba II, Heymach JV, Lippman SM, Desgrosellier JS, Anand S, Weis SM, Cheresh DA: An integrin $\beta_{3}$-KRAS-RalB complex drives tumour stemness and resistance to EGFR inhibition. Nat Cell Biol 2014, 16:457-468.

14. Desgrosellier JS, Barnes LA, Shields DJ, Huang M, Lau SK, Prévost N, Tarin D, Shattil SJ, Cheresh DA: An integrin alpha(v)beta(3)-c-Src oncogenic unit promotes anchorage-independence and tumor progression. Nat Med 2009, 15:1163-1169.

15. Chien Y, Kim S, Bumeister R, Loo Y-M, Kwon SW, Johnson CL, Balakireva MG, Romeo Y, Kopelovich L, Gale M Jr, Yeaman C, Camonis JH, Zhao Y, White MA: RalB GTPase-mediated activation of the IkappaB family kinase TBK1 couples innate immune signaling to tumor cell survival. Cell 2006, 127:157-170.

16. Li J, Huang J, Jeong J-H, Park S-J, Wei R, Peng J, Luo Z, Chen YT, Feng Y, Luo J-L: Selective TBK1/IKKi dual inhibitors with anticancer potency. Int J Cancer 2014, 134:1972-1980. 
17. Bailey ST, Miron PL, Choi YJ, Kochupurakkal B, Maulik G, Rodig SJ, Tian R, Foley KM, Bowman T, Miron A, Brown M, Iglehart JD, Biswas DK: NF-KB activation-induced anti-apoptosis renders HER2-positive cells drug resistant and accelerates tumor growth. Mol Cancer Res 2014, 12:408-420.

18. Combination therapy of bortezomib with novel targeted agents: an emerging treatment strategy. [http://clincancerres.aacrjournals.org].

doi:10.1186/s13058-014-0448-0

Cite this article as: Brown and Wendt: Integrin-mediated resistance to epidermal growth factor receptor-targeted therapy: an inflammatory situation. Breast Cancer Research 2014 16:448. 